\title{
A Combined Cell-Free Protein Synthesis and Fluorescence- Based Approach to Investigate GPCR Binding Properties
}

\author{
Anne Zemella, Theresa Richter, Lena Thoring, and Stefan Kubick
}

\begin{abstract}
Fluorescent labeling of de novo synthesized proteins is in particular a valuable tool for functional and structural studies of membrane proteins. In this context, we present two methods for the site-specific fluorescent labeling of difficult-to-express membrane proteins in combination with cell-free protein synthesis. The cell-free protein synthesis system is based on Chinese Hamster Ovary Cells (CHO) since this system contains endogenous membrane structures derived from the endoplasmic reticulum. These so-called microsomes enable a direct integration of membrane proteins into a biological membrane. In this protocol the first part describes the fluorescent labeling by using a precharged tRNA, loaded with a fluorescent amino acid. The second part describes the preparation of a modified aminoacyl-tRNA-synthetase and a suppressor tRNA that are applied to the $\mathrm{CHO}$ cell-free system to enable the incorporation of a non-canonical amino acid. The reactive group of the non-canonical amino acid is further coupled to a fluorescent dye. Both methods utilize the amber stop codon suppression technology. The successful fluorescent labeling of the model $G$ protein-coupled receptor adenosine $A_{2 A}$ (Adora2a) is analyzed by in-gel-fluorescence, a reporter protein assay, and confocal laser scanning microscopy (CLSM). Moreover, a ligand-dependent conformational change of the fluorescently labeled Adora2a was analyzed by bioluminescence resonance energy transfer (BRET).
\end{abstract}

Key words Cell-free protein synthesis, G protein-coupled receptor, Protein modification, Noncanonical amino acids, Amber suppression, Confocal laser scanning microscopy

\section{Introduction}

G protein-coupled receptors (GPCRs) are involved in vital processes including the regulation of signaling pathways and the subsequent triggering of essential physiological responses. Up to date more than $50 \%$ of pharmaceutical drugs are targeting GPCRs and GPCR interaction partners [1]. Therefore, the development of novel production processes of GPCRs for structural and functional characterization remains essential. In a natural environment, membrane proteins are only present in small concentrations [2]. The overexpression of membrane proteins is usually performed in heterologous systems involving a complex vector design. Nevertheless, 
overexpression obstacles such as low solubility, cytotoxicity, and low stability can occur [3]. In addition, detergents used to solubilize membrane proteins often induce altered ligand binding properties [4]. Cell-free protein synthesis based on translationally active lysates represents an approved alternative for membrane protein synthesis. Eukaryotic cell lysates based on insect, $\mathrm{CHO}$, and human cell lines are predestined for membrane protein synthesis due to the presence of endogenous membrane structures [5]. These microsomes enable an integration of membrane proteins into a biological membrane. In addition, posttranslational modifications such as disulfide bridging, phosphorylation, and partly glycosylation are possible [6]. Furthermore, the $\mathrm{CHO}$ cell-free system is characterized by a high productivity of complex proteins [7].

In the context of protein modification and fluorescent labeling by using genetic code expansion [8], cell-free systems are of special interest due to their open reaction mode [9]. Exogenously prepared components can be easily and directly added to the cellfree protein synthesis reaction to incorporate a defined non-canonical amino acid site-specifically at the position of a redefined codon within the gene sequence [10]. In a first step, addressing of a defined amber stop codon can be verified by the addition of a precharged tRNA to the cell-free protein synthesis reaction. The tRNAs in this report are aminoacylated to a lysine residue that is coupled to a Bodipy TMR dye (BP). The tRNA recognizes either the amber stop codon or the phenylalanine codon. The lysine residue with the coupled fluorescent dye is subsequently sitespecifically (BP-CUA) or statistically (BP-GAA) incorporated. The lack of a re-aminoacylating mechanism of the tRNA leads to the consumption of large amounts of precharged tRNA. Therefore, we describe an alternative system that is inspired by the natural aminoacylation of tRNAs in vivo.

The addition of non-canonical amino acids in vivo that usually do not permeate the cell wall can be realized in cell-free systems due to the missing cell wall. Even high concentrations of non-canonical amino acids can be added to the reaction. Moreover, the suppressor tRNA and the modified aminoacyl-tRNA-synthetase can be applied to the cell-free reaction in defined concentrations enabling an identification of optimal concentrations for highest suppression efficiency. Here, the described experimental setup is based on an evolved aminoacyl tRNA-synthetase (aaRS) derived from E.coli $[11,12]$ and a modified suppressor tRNA recognizing the UAG amber stop codon [13]. The combination of the aaRS, tRNA, and a phenylalanine-derivate (p-propargyloxy-L-phenylalanine, $\mathrm{pPa}$ ) with an alkyne group in para-position resulted in an efficient incorporation of the non-canonical amino acid into the model protein adenosine $\mathrm{A}_{2 \mathrm{~A}}$ receptor (Adora2a). The human Adora2a is expressed in almost every tissue of the body. Primarily, the membrane protein 
can be detected in the brain, cells of the immune system, leucocytes, and platelets. In peripheral tissues, the Adora2a is involved in inflammation reactions and affects the control of the cardiovascular system [14]. The interaction of the Adora2a with different neurotransmitters in the brain is of highest interest since the receptor displays an important role in the regulation of dopamine and glutamate release thereby making it a promising therapeutic target for the treatment of depression, insomnia, and Parkinson's disease [15]. Consequently, a better understanding of the detailed interactions between membrane proteins and their specific ligands is mandatory. Information on the structural and functional relationship of a defined GPCR might be gained by a visualization of the target membrane protein in a nature-like lipid environment [14]. A highly preferred method to determine GPCR interaction is based on the spatial proximity of two fluorescent moieties. Interaction partners can be determined by an intermolecular fluorescence resonance energy transfer (FRET) and specific conformation changes by an intramolecular FRET. For the Adora2a, intermolecular as well as intramolecular FRETs were established to analyze the receptors' behavior $[16,17]$. In this way, the conformational rearrangement of the helices III and VI induced by agonist binding was elucidated [18]. A coupled fluorescent dye in the region of amino acid 215 will be excited by a C-terminally fused NanoLuciferase (Nluc) resulting in a detectable bioluminescence resonance energy transfer (BRET). A signal change of the BRET value after the addition of a ligand indicates a conformational change of the Adora2a. The main objective of this chapter is to describe a cell-free protein synthesis-based alternative methodology to the standard protein visualization methods typically used in vivo. Our cell-free procedure is based on the site-specific and statistical incorporation of a precharged tRNA and a site-specific incorporation of a non-canonical amino acid into the target protein. The cell-free synthesized protein is subsequently labeled by using a chemoselective reaction. Moreover, we adapted an intramolecular BRET for the Adora2a to show a ligand-dependent conformational change. In addition, we present the preparation of the evolved aminoacyl-tRNA-synthetase and the suppressor tRNA.

\section{Materials}

\subsection{Preparation of Enhanced Orthogonal Aminoacyl- tRNA-Synthetase}

1. Coding sequence for the modified tyrosyl-tRNA-synthetase (eAzFRS, including the mutations Thr37, Ser182, Alal83, and Arg265 [11, 12] and a C-terminal Strep-Tag) from E.coli.

2. E.coli expression system (RTS 500 E.coli HY Kit, biotechrabbit).

3. $100 \mathrm{mM}$ Isopropyl $\beta$-D-1-thiogalactopyranoside (IPTG). 


\subsection{Preparation of Suppressor tRNA}

2.2.1 Generation of PCR Product
2.2.2 Generation of RNA Transcript
4. Gravity flow Strep-Tactin ${ }^{\circledR}$ superflow mini-column $(0.2 \mathrm{ml})$.

5. Strep-Tactin ${ }^{\circledR}$ Purification Buffer Set: $10 \times$ Washing Buffer (1 M Tris-Cl, pH 8.0, $1.5 \mathrm{M} \mathrm{NaCl}, 10 \mathrm{mM}$ EDTA), $10 \times$ Elution Buffer (1 M Tris-Cl, pH 8.0, 1.5 M NaCl, $10 \mathrm{mM}$ EDTA, $25 \mathrm{mM}$ Desthiobiotin) and $10 \times$ Regeneration Buffer (1 M Tris-Cl, 1.5 M NaCl, $10 \mathrm{mM}$ EDTA, $10 \mathrm{mM}$ HABA (hydroxyl-azophenyl-benzoic acid)).

6. Zeba ${ }^{\mathrm{TM}}$ Spin Desalting Columns (7 K MWCO, $0.5 \mathrm{ml}$ ).

7. Amicon ${ }^{\circledR}$ Ultra Centrifugal Filters ( $10 \mathrm{~K}$ device, $0.5 \mathrm{ml}$ ).

8. Synthetase storage buffer: $50 \mathrm{mM}$ HEPES pH 7.6, $10 \mathrm{mM}$ KOAc, $1 \mathrm{mM} \mathrm{MgCl} 2,4 \mathrm{mM}$ DTT.

9. Thermomixer with a microtiter plate adapter and a RTS 500 adapter.

1. Vector containing the nucleotide sequence of tRNATyrCUA (SupF Gene).

2. tRNATyrCUA-specific forward primer $\left(5^{\prime} \mathrm{CgA}\right.$ gCT $\mathrm{CgC}$ CCA CCg gAA TTC $3^{\prime}$ ) and $2^{\prime}$-OMe reverse primer ( $5^{\prime} \mathrm{Tgg}$ Tgg Tgg ggg AAg gAT TCg $3^{\prime}$ ).

3. $0.2 \mathrm{ml}$ PCR tubes.

4. PCR cycler.

5. Taq DNA polymerase.

6. Taq buffer.

7. dNTPs.

8. $25 \mathrm{mM} \mathrm{MgCl}_{2}$.

9. Agarose gel electrophoresis chambers.

10. Agarose.

11. Rotiphorese $10 \times$ TBE buffer.

12. DNA stain.

13. DNA ladder.

14. PCR Purification Kit.

1. T7 RNA Polymerase (f.c. $1 \mathrm{U} / \mu \mathrm{l}$, Agilent).

2. $5 \times$ NTP mix containing $18.75 \mathrm{mM}$ ATP, $18.75 \mathrm{mM}$ CTP, $18.75 \mathrm{mM}$ UTP and $7.5 \mathrm{mM}$ GTP.

3. $5 \times$ transcription buffer: $400 \mathrm{mM}$ HEPES-KOH, $0.5 \mathrm{mM}$ Spermidine, $50 \mathrm{mM} \mathrm{DTE}$ and $75 \mathrm{mM} \mathrm{MgCl}_{2}$.

4. DNAseI ( 1 U per $\mu$ g plasmid DNA).

5. $10 \times$ MOPS buffer: $200 \mathrm{mM}$ MOPS, $50 \mathrm{mM} \mathrm{NaOAc}, 10 \mathrm{mM}$ EDTA, pH 8.0. 
2.2.3 RNA Isolation and Folding

2.3 Cell-Free Protein Synthesis and Fluorescent Labeling of Modified Adora2a
6. MOPS sample buffer: $8 \%(\mathrm{v} / \mathrm{v})$ formaldehyde, $12 \mathrm{ml}$ formamide, $2.4 \mathrm{ml} 10 \times$ MOPS buffer, $0.05 \%(\mathrm{v} / \mathrm{v})$ bromophenol blue to a total volume of $24 \mathrm{ml}$.

1. TRIzol reagent.

2. High Performance Liquid Chromatography (HPLC) grade Chloroform.

3. HPLC grade Isopropyl.

4. $75 \%$ Ethanol.

5. Cooled centrifuge.

6. Nanodrop 2000c.

1. Coding sequence for the modified adenosine $\mathrm{A}_{2 \mathrm{~A}}$ receptor (Uniprot: P29274, amino acids 1-340, with and without amber stop codon at nucleotide sequence coding for P215) with a receptor C-terminally fused Nanoluciferase (Fig. 1). Flanking sequences containing $5^{\prime}$ regulatory sequences (T7 RNA polymerase promotor, Cricket paralysis virus (CRPV) IGR IRES sequence (Genbank accession no. AF218039, nucleotides 6025-6216)) and $3^{\prime}$ regulatory sequences (T7 terminator), cloned with the coding sequence into a plasmid (BioCat or Thermo Fisher Scientific).

2. $1.5 \mathrm{ml}$ reaction tubes.

3. CHO lysate prepared as described $[19,20]$ ( see Note 1).

4. $10 \times$ translation mix: $300 \mathrm{mM}$ HEPES-KOH $(\mathrm{pH}$ 7.6), $2250 \mathrm{mM}$ KOAc, $2.5 \mathrm{mM}$ spermidine, $1 \mathrm{mM}$ of each canonical amino acid (Merck) and $39 \mathrm{mM} \mathrm{Mg}(\mathrm{OAc})_{2}$.

5. $5 \times$ energy: $100 \mathrm{mM}$ creatine phosphate, $1.5 \mathrm{mM}$ GTP, $1.5 \mathrm{mM}$ CTP, $1.5 \mathrm{mM}$ UTP $8.75 \mathrm{mM}$ ATP and $0.5 \mathrm{mM}$ $\mathrm{m}^{7} \mathrm{G}(\mathrm{ppp}) \mathrm{G}$ cap analogue.

6. $100 \mu \mathrm{M}$ Polyguanylic acid (polyG, IBA).

7. T7 RNA polymerase (f.c. $1 \mathrm{U} / \mu \mathrm{l}$ ).

8. ${ }^{14} \mathrm{C}$-leucine.

9. $100 \mu \mathrm{M} \quad$ Bodipy-TMR-lysine-tRNACUA (BP-CUA, biotechrabbit).

10. $100 \mu \mathrm{M} \quad$ Bodipy-TMR-lysine-tRNAGAA (BP-GAA, biotechrabbit).

11. $100 \mu \mathrm{M}$ eAzFRS.

12. $100 \mu \mathrm{M}$ tRNATyrCUA.

13. $100 \mathrm{mM}$ p-propargyloxy-L-phenylalanine (pPa, Iris Biotech).

14. $5 \mathrm{mM}$ Copper(II) sulfate $\left(\mathrm{CuSO}_{4}\right)$. 


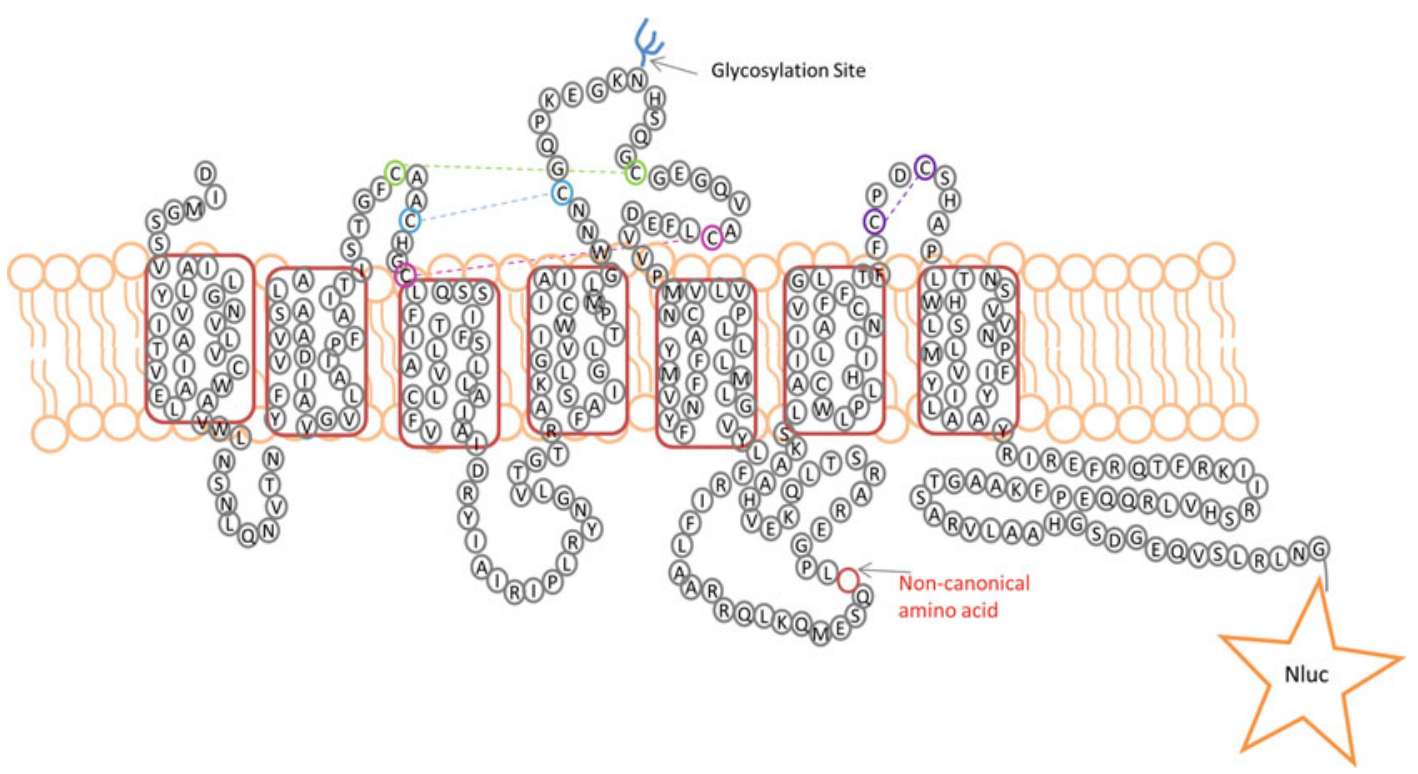

Fig. 1 Schematic illustration of the Adora2a receptor with a C-terminally fused Nluc. Arrows indicate the glycosylation site and the position of the non-canonical amino acid. Disulfide bridges are indicated by the colors green, blue, pink, and purple

\subsection{Analysis}

of De Novo

Synthesized Proteins
15. $2.5 \mathrm{mM}$ Tris(3-hydroxypropyltriazolylmethyl)amine (THPTA, Iris Biotech).

16. $80 \mathrm{mM}$ Sodium ascorbate (NaAsc).

17. Phosphate-buffered saline (PBS).

18. $100 \mu \mathrm{M}$ Sulfo-Cy5-azide (Lumiprobe).

1. Trichloroacetic acid (TCA).

2. Water bath.

3. Glass fiber filters.

4. Acetone.

5. Scintillation vials.

6. Scintillation cocktail.

7. Scintillation counter.

8. SDS-PAGE Sample buffer: $1 \times$ LDS buffer containing $106 \mathrm{mM}$ Tris- $\mathrm{HCl}, 141 \mathrm{mM}$ Tris base, $2 \%$ LDS, $10 \%$ glycerol, $0.51 \mathrm{mM}$ EDTA, $0.22 \mathrm{mM}$ SERVA Blue G, $0.175 \mathrm{mM}$ Phenol Red, pH 8.5 with $50 \mathrm{mM}$ DTT.

9. SDS-PAGE gels.

10. Fluorescently labeled protein ladder for SDS-PAGE.

11. Fluorescence/phosphorimager.

12. Gel dryer. 
13. Phosphorscreens.

14. Adenosine.

15. Nano-Glo ${ }^{\circledR}$ Luciferase Assay System.

16. 96-well microtiter plate.

17. Multimode Microplate Reader Mithras ${ }^{2}$ LB 943.

18. $\mu$-Ibidi-Slide ( $\mu$-Slide 18 well, flat, Ibidi).

19. Confocal laser scanning microscope.

\section{Methods}

\subsection{Preparation of Enhanced Orthogonal Aminoacyl- tRNA-Synthetase}

1. For prokaryotic cell-free synthesis, the eAzFRS gene should be cloned into a vector containing a T7 promotor, ribosomal binding site, and T7 terminator such as pIX3.0, pIVEX2.3d, and pIVEX $2.4 \mathrm{~d}$ vectors or alternatively containing a T5 promotor such as pQE2 vectors as used in this protocol. eAzFRS is synthesized in a cell-free system using an $E$. coli lysate in a dialysis mode. A typical $1.1 \mathrm{ml}$ reaction is composed of $0.525 \mathrm{ml}$ E.coli lysate, $0.225 \mathrm{ml}$ reaction $\mathrm{mix}, 0.27 \mathrm{ml}$ amino acids without methionine, $30 \mu \mathrm{l}$ methionine, $11 \mu \mathrm{l}$ IPTG for the induction of the protein expression pQE2 vector, $39 \mu \mathrm{l}$ template containing $110 \mu \mathrm{g}$ plasmid DNA.

2 . The surrounding feeding mixture contains $7990 \mu \mathrm{l}$ feeding mix, $110 \mu \mathrm{l}$ IPTG, $2650 \mu \mathrm{l}$ amino acids without methionine and $300 \mu \mathrm{l}$ methionine (see Note 2 ).

3. Fill the reaction solution into the reaction compartment (marked through the red lid).

4. Fill the feeding mix into the feeding chamber (marked through the colorless lid).

5. Insert the prepared chamber into the RTS 500 adapter in a thermomixer. The reaction time is $20 \mathrm{~h}$ at $30{ }^{\circ} \mathrm{C}$ and a shaking speed of $900 \mathrm{rpm}$.

6. For the separation of aggregated proteins from soluble eAzFRS a centrifugation step at $16,000 \times g$ for $10 \mathrm{~min}$ at $4^{\circ} \mathrm{C}$ is recommended.

7. Equilibrate two Strep-Tactin columns with $400 \mu \mathrm{l}$ of $10 \times$ washing buffer and add $500 \mu \mathrm{l}$ of the supernatant of the cellfree reaction to each column.

8. After the supernatant has completely entered the column, wash each column $5 \times$ with $200 \mu$ l washing buffer (see Note 3 ).

9. Elute the protein $6 \times$ with $100 \mu$ l elution buffer and collect the fractions.

10. Elution fractions containing the target protein are pooled. 


\subsection{Preparation of Suppressor tRNA}

3.2.1 Generation of PCR Product

3.2.2 Generation of RNA Transcript
11. Regenerate the column with $3 \times 1 \mathrm{ml}$ of $1 \times$ regeneration buffer and remove the regeneration buffer $2 \times$ with $800 \mu \mathrm{l}$ of $1 \times$ washing buffer. Store the column in $2 \mathrm{ml}$ washing buffer at $4{ }^{\circ} \mathrm{C}$.

12. The combined elution fractions are applied to Zeba ${ }^{\mathrm{TM}}$ Spin Desalting Columns to exchange the elution buffer of the strep-tag purification to a synthetase storage buffer. Therefore, remove the storage solution of the Zeba ${ }^{\mathrm{TM}}$ Spin Desalting Column by centrifugation at $1500 \times g$ for $1 \mathrm{~min}$. Add $300 \mu \mathrm{l}$ of the synthetase storage buffer to the resin bed and centrifuge at $1500 \times g$ for $1 \mathrm{~min}$. Repeat this step $2 \times$. Place the column in a new collection tube and apply $100 \mu$ of the pooled synthetase solution to each column. Centrifuge at $2000 \times g$ for $2 \mathrm{~min}$ and collect the synthetase.

13. The concentration of the synthetase can be performed with Amicon ${ }^{\circledR}$ Ultra Centrifugal Filters. Add up to $500 \mu$ l of the synthetase solution to the concentrator and centrifuge at $14,000 \times g$ for $10 \mathrm{~min}$ and $4{ }^{\circ} \mathrm{C}$. Collect the concentrated sample and determine the concentration by NanoDrop measurement using the molecular mass $(48.6 \mathrm{kDa})$ and the extinction coefficient (54.3) (see Note 4).

14. The synthetase can be stored at $-80{ }^{\circ} \mathrm{C}$ after shock freezing in liquid nitrogen.

1. For specific and homogenous $3^{\prime}$-ends of the suppressor tRNA, an additional PCR step before transcription reaction is included. Therefore, the reverse primer contains a $2^{\prime}$-OMegroup to prevent unspecific nucleotides at the $3^{\prime}$-end of the tRNA that can be added by the T7 polymerase during transcription reaction. Amplify the template by pipetting in a PCR tube final concentrations of $1 \times$ Taq Buffer, $0.2 \mathrm{mM} \mathrm{dNTP}$ mix, $0.5 \mu \mathrm{M}$ forward primer, $0.5 \mu \mathrm{M}$ reverse primer, $2.5 \mathrm{mM}$ $\mathrm{MgCl}_{2}, 0.01 \mathrm{ng} / \mu \mathrm{l}$ plasmid and $0.04 \mathrm{U} / \mu \mathrm{l}$ Taq DNA polymerase. Fill the reaction with water to a final volume of $250 \mu \mathrm{l}$ (see Note 5 ).

1. Thaw the components for in vitro transcription on ice and pipette the reaction at room temperature. Mix $1 \times$ transcription buffer, $1 \times$ NTP mix, $1 \mathrm{U} / \mu \mathrm{l}$ T7 RNA Polymerase and $8 \mathrm{ng} / \mu \mathrm{l}$ template DNA. Fill the reaction with water to the final volume of $500 \mu \mathrm{l}$. Incubate the reaction for $3-6 \mathrm{~h}$ at $37^{\circ} \mathrm{C}$ and $500 \mathrm{rpm}$.

2. Centrifuge the RNA at $12,000 \times g$ for $1 \mathrm{~min}$ und use the supernatant for the DNAseI treatment (see Note 6) Add $1 \mathrm{U}$ DNAseI per $1 \mu \mathrm{g}$ DNA. Incubate for $10 \mathrm{~min}$ at $37^{\circ} \mathrm{C}$ and $500 \mathrm{rpm}$. 
3.2.3 RNA Isolation and Folding

\subsection{Cell-Free Protein Synthesis}

3.3.1 Fluorescent Labeling with Bodipy-TMRLysine
1. Handle the TRIzol and chloroform reagent with care and use a fume hood. Add a threefold volume of TRIzol to the transcription reaction and mix carefully. Incubate for $5 \mathrm{~min}$ at room temperature. Add $200 \mu \mathrm{l}$ chloroform for $1 \mathrm{ml}$ TRIzol and mix carefully for $15 \mathrm{~s}$ by inverting. Incubate for $3 \mathrm{~min}$ at room temperature. Centrifuge at $12,000 \times g$ for $15 \mathrm{~min}$ at $4{ }^{\circ} \mathrm{C}$. Isolate the aqueous phase (see Note 7 ). Add $500 \mu \mathrm{l}$ isopropyl for $1 \mathrm{ml} \mathrm{TRIzol}$ and mix carefully. Incubate overnight at $4{ }^{\circ} \mathrm{C}$.

2. Centrifuge at $15,000 \times g$ at least for $1 \mathrm{~h}$ at $4{ }^{\circ} \mathrm{C}$ and discard the supernatant. Overlay the pellet with $1 \mathrm{ml} 75 \%$ ethanol for $1 \mathrm{ml}$ TRIzol and incubate for $30 \mathrm{~min}$ at $-20{ }^{\circ} \mathrm{C}$. Centrifuge at $7500 \times g$ for $10 \mathrm{~min}$ and $4{ }^{\circ} \mathrm{C}$. Discard the supernatant and air dry the pellet. Solve the pellet in water. Measure concentration using a NanoDrop and adjust the concentration to $100 \mu \mathrm{M}$.

3 . Fold the tRNA by slowly decreasing the temperature from 80 to $25^{\circ} \mathrm{C}$ in a PCR cycler. The tRNA can be stored at $-80{ }^{\circ} \mathrm{C}$ after shock freezing in liquid nitrogen.

1. Thaw all required components for cell-free protein synthesis on ice (see Note 8).

2 . The cell-free protein synthesis is performed in a coupled mode where transcription and translation reaction take place in one vessel. A standard reaction is composed of $40 \% \mathrm{CHO}$ lysate, $10 \mu \mathrm{M}$ polyG, $1 \times$ translation mix, and $1 \times$ energy mix. Add plasmid at a concentration of $40 \mathrm{nM}$ ( see Note 9). Add $\mathrm{l} U / \mu \mathrm{l}$ T7 RNA polymerase for the transcription reaction and ${ }^{14} \mathrm{C}$ leucine (specific radioactivity of $66.67 \mathrm{dpm} / \mathrm{pmol}$ ) for further analysis of de novo synthesized proteins. Fill the reaction with water to the final volume of $50 \mu \mathrm{l}$.

1. Thaw the Bodipy-TMR-lysine-tRNACUA (BP-CUA) and Bodipy-TMR-lysine-tRNAGAA (BP-GAA) on ice and keep it dark (see Note 10).

2. Pipette $2 \mu \mathrm{M}$ of the precharged tRNA to the cell-free reaction and incubate the prepared cell-free protein synthesis reaction by $27^{\circ} \mathrm{C}$ for $3 \mathrm{~h}$ and shaking at $600 \mathrm{rpm}$ ( see Note 11). Cover the thermomixer with a lid or aluminum foil to prevent the reaction of any light.

3. Take a $5 \mu \mathrm{l}$ aliquot of the translation mixture for SDS-PAGE. Centrifuge the translation reaction for $15 \mathrm{~min}$ at $16,000 \times g$ and $4{ }^{\circ} \mathrm{C}$. Take a $5 \mu \mathrm{l}$ of the supernatant and resuspend the pellet (microsomal fraction) in an equal volume PBS in comparison to the volume of the translation reaction. This step is required for the analysis of the localization of the synthesized 
Table 1

Expectations of cell-free protein synthesis and fluorescent labeling of different Adora2a constructs with Bodipy-tRNA directed to phenylalanine codons (GAA) or directed to the amber stop codon (CUA)

\begin{tabular}{|c|c|c|c|}
\hline \multirow[b]{2}{*}{ Construct } & \multirow{2}{*}{$\begin{array}{l}\text { Precharged } \\
\text { tRNA }\end{array}$} & \multicolumn{2}{|l|}{ Expectation } \\
\hline & & Synthesis & Fluorescence \\
\hline Adora2a & BP-GAA & Full-length protein & $\begin{array}{l}\text { Highly fluorescently labeled protein with } \\
\text { statistical incorporation of ncAA }\end{array}$ \\
\hline Adora2a & BP-CUA & Full-length protein & $\begin{array}{l}\text { The full-length protein is not labeled with the } \\
\text { fluorescent dye and the ncAA is not } \\
\text { incorporated. }\end{array}$ \\
\hline Adora2a_amb & BP-CUA & $\begin{array}{l}\text { Full-length protein and } \\
\text { partial termination } \\
\text { product }\end{array}$ & $\begin{array}{l}\text { The full-length protein is fluorescently labeled. } \\
\text { The fluorescence signal has a lower intensity } \\
\text { in comparison to the statistically labeled } \\
\text { Adora2a due to the site-specific incorporation } \\
\text { of the ncAA at one defined position. } \\
\text { Termination product is not labeled. }\end{array}$ \\
\hline Adora2a_amb & BP-GAA & Termination product & $\begin{array}{l}\text { The termination product is highly fluorescently } \\
\text { labeled due to the statistical incorporation of } \\
\text { the ncAA. No full-length product is visible. }\end{array}$ \\
\hline
\end{tabular}

protein. The expectations of the incorporation of the different Bodipy-tRNAs are described in Table 1 ( see Note 12).

4. An example of the performance of the fluorescent labeling of Adora2a with or without incorporated non-canonical amino acid determined by in-gel-fluorescence and autoradiography, and the measurement of the reporter protein are shown in Fig. 2. In-gel-fluorescence and autoradiography (Fig. 2a, c) showed the expected results as described in Table 1 . The reporter protein assay (Fig. 2b) is based on the activity of a receptor C-terminally fused Nanoluciferase (Nluc). Nluc activity can only be measured after the translation of the full-length fusion protein. The Adora2a synthesized by using the DNA construct without an amber stop codon (Adora2a + BP-GAA/ BP-CUA) resulted in a fusion protein with a detectable Nluc activity. The fusion protein translated from the amber stop codon DNA construct (Adora2a_amb + BP-CUA) showed a fivefold reduced Nluc activity. This result implicates a rather low incorporation efficiency of the precharged tRNA addressing the amber stop codon. The combination of Adora2a_amb with BP-GAA showed no luciferase activity since only the termination product was translated. Protein yields were calculated by scintillation counting and resulted in approximately $20 \mu \mathrm{g} / \mathrm{ml}$ in translation mixture. In the microsomal fraction and the supernatant, approximately $6 \mu \mathrm{g} / \mathrm{ml}$ and $14 \mu \mathrm{g} / \mathrm{ml}$ were detected, respectively. A similar Adora2a distribution was 
A
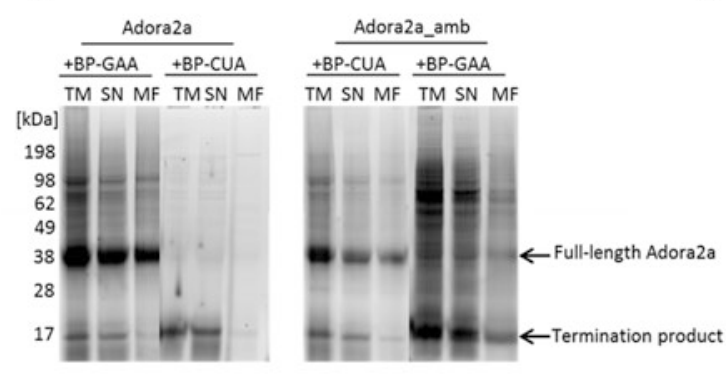

C

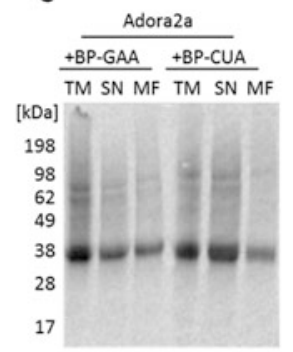

B

D
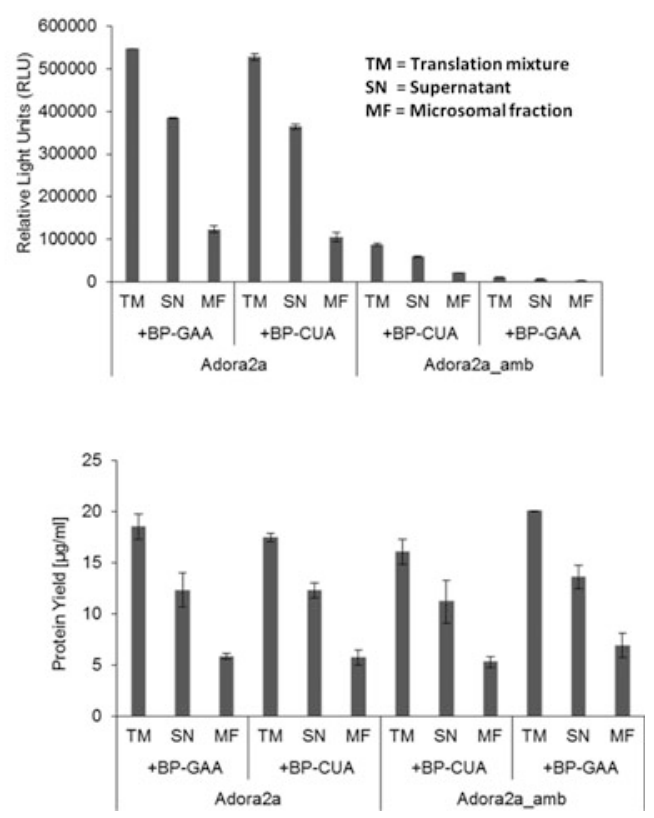

Fig. 2 Analysis of fluorescent labeling by using precharged tRNAs. (a) In-gel-analysis of Adora2a by statistical and site-specific incorporation of a fluorescently labeled amino acid. The translation mixture (TM) was fractionated into supernatant (SN) and microsomal fraction (MF). (b) Analysis of the translation of a reporter protein (Nluc) fused to the C-terminus of Adora2a by measuring the luminescence of the Nluc. (c) Autoradiographic analysis of de novo synthesized Adora2a by incorporation of ${ }^{14} \mathrm{C}$-leucine during the cell-free synthesis reaction. (d) Determination of protein yield of de novo synthesized Adora2a by scintillation counting

3.3.2 Analysis of LigandDependent Conformational Change Using a BRET Assay obtained by in-gel-fluorescence, luciferase activity, and autoradiography. Previously reported distributions of membrane proteins are comparable to the here described distribution [7]. A comparable protein yield was calculated for the termination product.

1. Site-specifically label the Adora2a_amb using the precharged tRNA Bodipy-TMR-lysine-tRNACUA as described in Subheading 3.3.1, steps $\mathbf{1}-\mathbf{3}$.

2. Resuspend the microsomal fraction of the Adora2a_amb in PBS. $5 \mu \mathrm{l}$ aliquots of resuspended Adora2a_amb were mixed with $5 \mu \mathrm{l}$ adenosine in PBS with final concentrations of $0 \mu \mathrm{M}$, $100 \mu \mathrm{M}, 1000 \mu \mathrm{M}$, and $5000 \mu \mathrm{M}$ adenosine (see Note 13).

3. $10 \mu \mathrm{l}$ samples were applied for the luminescence and fluorescence measurement. In a first step, the luminescence of the Nluc was detected using an OD2 filter. In a second step, the fluorescence of the coupled Bodipy dye, excited by the Nluc emission was detected.

4. As a control $5 \mu l$ of the resuspended microsomal fraction of the full-length Adora2a protein without any fluorescent label is 


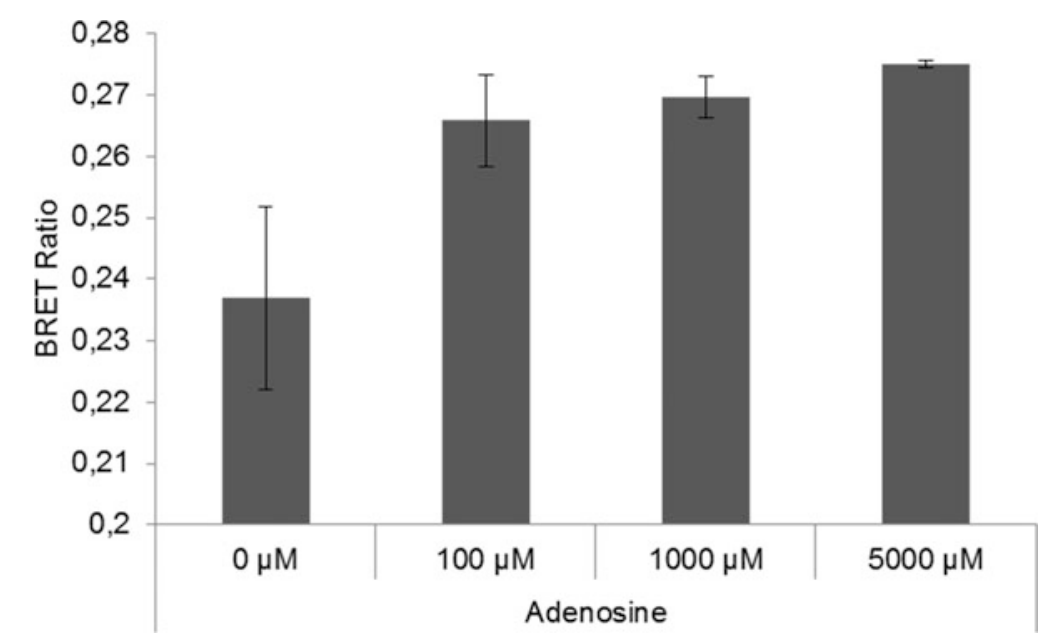

Fig. 3 BRET signal of the fluorescently labeled Adora2a_amb after adenosine binding. Cell-free synthesized and fluorescently labeled Adora2a_amb was subjected to luminescence and fluorescence analysis in presence of different adenosine concentrations $(0-5000 \mu \mathrm{M})$. The ratio of the Bodipy fluorescence to the luminescence of the Nluc was calculated and subtracted by a control ratio

treated with the same concentrations of adenosine (step 2) to determine background fluorescence caused by the broad emission spectrum of the Nluc and possible interactions of adenosine with the Nluc.

5. The BRET ratio is calculated as follows:

$\mathrm{BRET}_{\text {ratio }}=\frac{\text { Fluorescence }(\text { sample })}{\text { Luminescence }(\text { sample })}-\frac{\text { Fluorescence }(\text { control })}{\text { Luminescence }(\text { control })}$

6. Herein, the calculated BRET ratio (Fig. 3) showed a change in the relation of the fluorescence of the Bodipy in comparison to the Nluc luminescence after the addition of different adenosine concentrations. Only a minimal increase of the BRET ratio can be seen after addition of higher adenosine concentrations (above $100 \mu \mathrm{M}$ ) indicating that at lower concentrations all receptors are occupied with adenosine. The result indicates a conformational change of the helix III and the connected third intracellular loop that is expected for the Adora2a.

3.3.3 Site-Specific Incorporation of a Non-canonical Amino Acid with Subsequent Fluorescent Labeling and Microscopic Analysis
1. Additional components are required for the recharging of the suppressor tRNA and a subsequent incorporation of a non-canonical amino acid. Therefore, add the p-propargyloxy-L-phenylalanine, tRNATyrCUA, and eAzFRS in a specific order (Table 2) (see Note 14). 


\section{Table 2}

Pipetting order of a standard cell-free reaction with orthogonal components for the incorporation of non-canonical amino acids

\begin{tabular}{lll}
\hline Order & Components & Final concentration \\
\hline 1 & Water & \\
\hline 2 & PolyG & $10 \mu \mathrm{M}$ \\
\hline 3 & Translation mix & $1 \times$ \\
\hline 4 & pPa & $2 \mathrm{mM}$ \\
\hline 5 & DNA-template & $40 \mathrm{nM}$ \\
\hline 6 & Lysate & $40 \%$ \\
\hline 7 & tRNATyrCUA & $3 \mu \mathrm{M}$ \\
\hline 8 & eAzFRS & $3 \mu \mathrm{M}$ \\
\hline 9 & 14 C-leucine & $66.67 \mathrm{dpm} / \mathrm{pmol}$ \\
\hline 10 & T7-RNA-Polymerase & $1 \mathrm{U} / \mu \mathrm{l}$ \\
\hline 11 & Energy mix & $1 \times$ \\
\hline
\end{tabular}

2. Incubate the prepared cell-free reaction at $27^{\circ} \mathrm{C}$ for $3 \mathrm{~h}$ by gentle shaking at $600 \mathrm{rpm}$. Keep the reaction in the dark (see Note 15).

3. The membrane protein is translocated and integrated into the microsomal membrane during the cell-free reaction. Therefore, separate the microsomal fraction by centrifugation at $16,000 \times g$ for $15 \mathrm{~min}$ at $4{ }^{\circ} \mathrm{C}$. Resuspend the pellet fraction in PBS. Use an equal volume of the cell-free reaction for resuspension.

4. For the labeling reaction prepare the labeling mix as follows: combine $200 \mu \mathrm{M} \mathrm{CuSO}_{4}$ with $600 \mu \mathrm{M}$ THPTA, $5 \mathrm{mM} \mathrm{NaAsc}$, PBS and a final concentration of $3 \mu \mathrm{M}$ Sulfo-Cy5-azid to a final volume of $5 \mu \mathrm{l}$. Add $5 \mu \mathrm{l}$ of the resuspended microsomal fraction to the labeling mix. Incubate the labeling reaction at room temperature for $1 \mathrm{~h}$. Keep the reaction dark (see Note 16).

5. Centrifuge the labeling reaction for $15 \mathrm{~min}$ at $16,000 \times g$ and $4{ }^{\circ} \mathrm{C}$. Discard the supernatant and resuspend the pellet in $10 \mu \mathrm{l}$ PBS. This step removes excess fluorescent dye to decrease the background signal in the subsequent fluorescent analyses.

6. The analysis of the synthesis of the full-length protein by using the Adora2a construct with or without an amber stop codon was performed by autoradiography and a reporter protein assay (Fig. 4). The autoradiography shows for both synthesis reactions a similar band pattern (Fig. 4a). Interestingly, the 
A
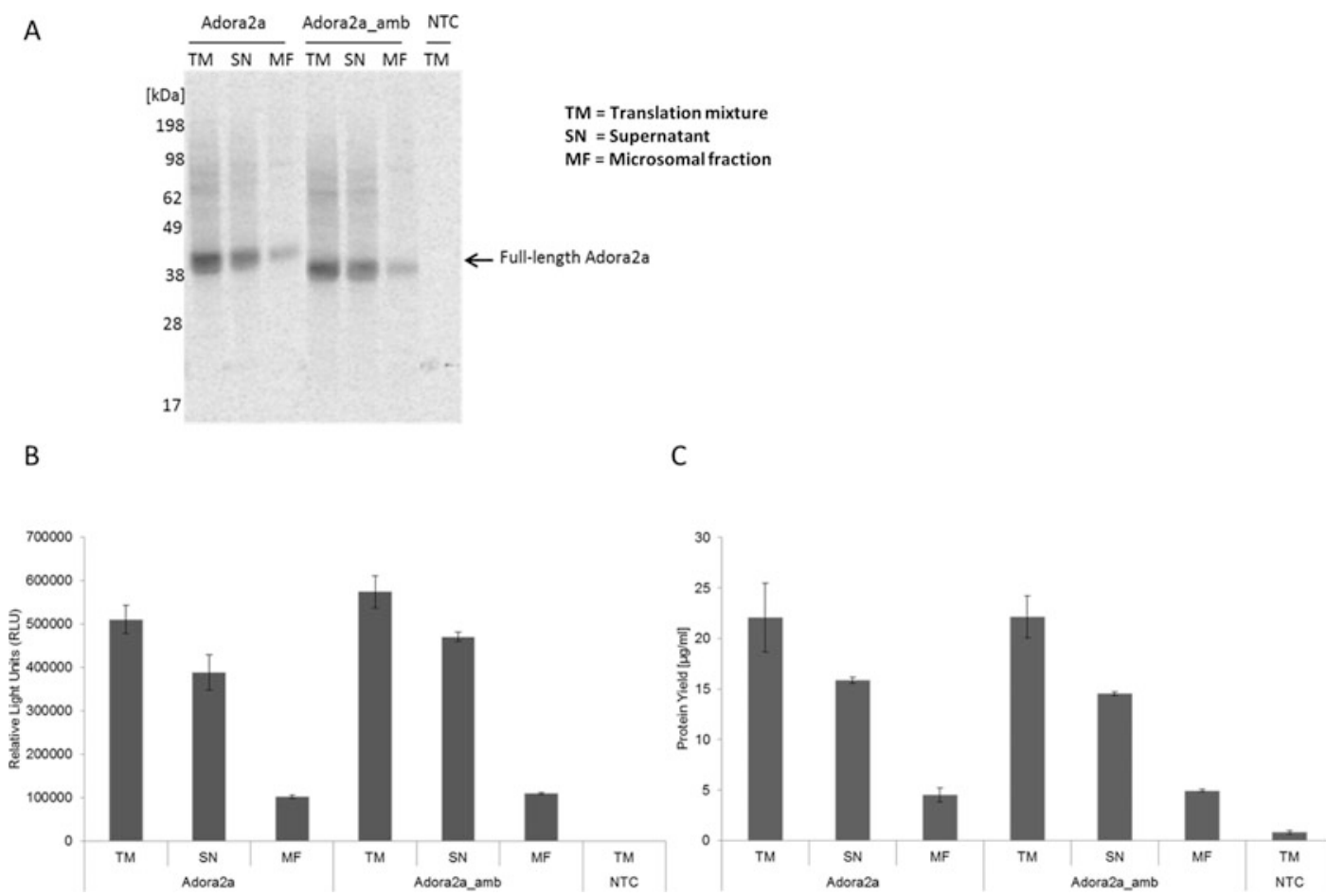

Fig. 4 Analysis of incorporation efficiency using an orthogonal system. (a) Autoradiography of synthesized Adora2a after incorporation of ${ }^{14} \mathrm{C}$-leucine. Translation mixture (TM) was fractionated into supernatant (SN) and microsomal fraction (MF). (b) Schematic illustration of subsequent labeling reaction after reaching a high incorporation of the non-canonical amino acid. (c) Analysis of the translation of a reporter protein (Nluc) fused to the C-terminus of Adora2a by measuring the luminescence of the luciferase. NTC $=$ no template control. (d) Protein yield of synthesized Adora2a, determined by scintillation counting

incorporation of $\mathrm{pPa}$ led to a comparable band signal as obtained for the full-length protein translated from the DNA construct without an amber stop codon. This result implicates a high incorporation efficiency of the non-canonical amino acid. In addition, no termination product is detected in the autoradiograph. The high incorporation efficiency is the basis for a further coupling reaction to a fluorescent dye. In addition, this result is supported by the Nluc assay (Fig. 4b). The measured luciferase activity of the suppression product reaches up to $80 \%$ of the luciferase activity of the full-length product. The protein yield and protein distribution (Fig. 4c) is comparable to the previously described results (Fig. 2, see Subheading 3.3.1, step 4).

7. Fluorescently labeled GPCRs should be detectable in microsomal structures (Fig. 5). It is recommended to visualize the labeled sample first by in-gel-fluorescence (Fig. 5, left panel). 


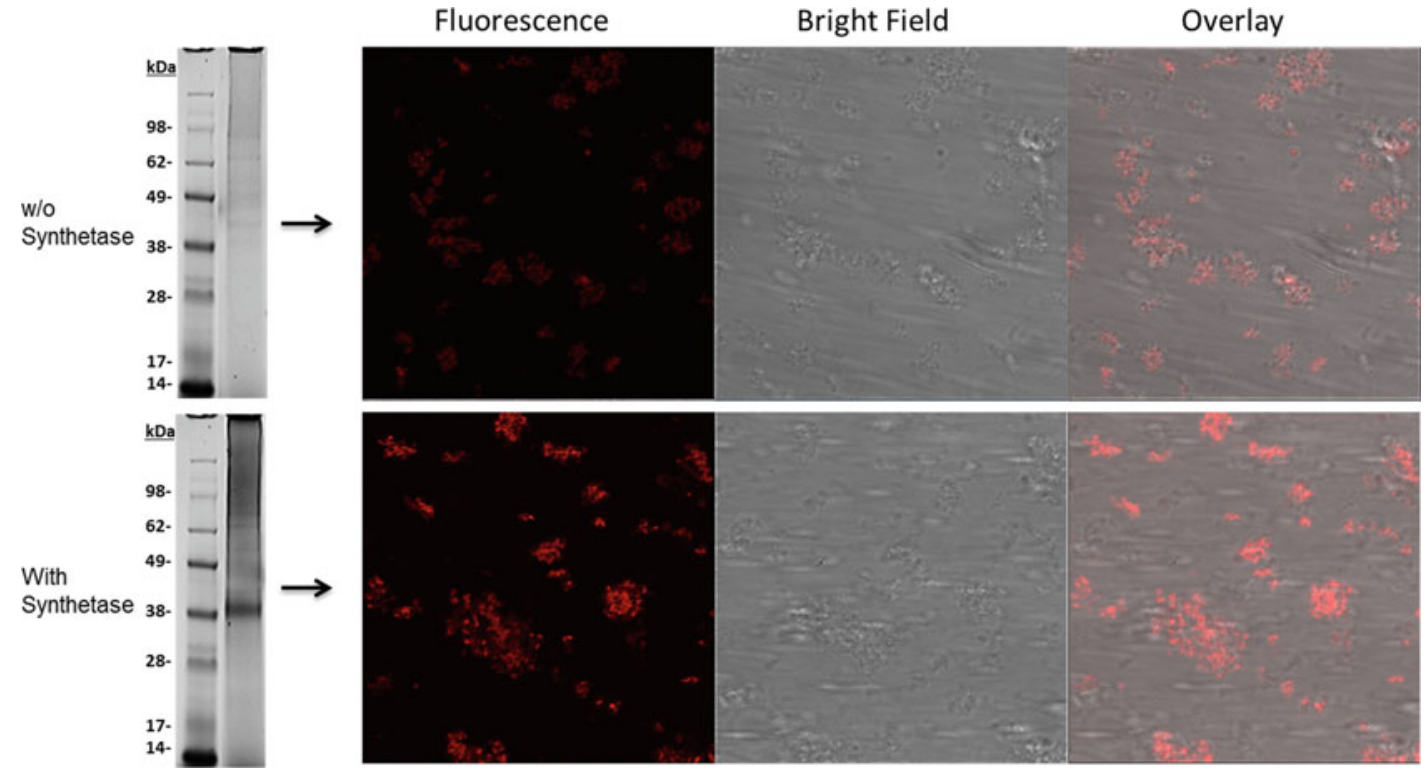

Fig. 5 Fluorescence analysis of labeled Adora2a. Left side: In-gel-fluorescence of synthesized and with SulfoCy5-azide labeled Adora2a in absence or presence of the modified synthetase during the cell-free protein synthesis reaction. Right side: confocal laser scanning microscopy of the control sample (without addition of the modified synthetase during cell-free protein synthesis) and the labeled Adora2a (cell-free protein synthesis in presence of the synthetase)

\subsection{Analysis \\ of De Novo}

\section{Synthesized}

\section{Fluorescent Proteins}

3.4.1 TCA Precipitation and Scintillation Counting
The synthesis reaction in the presence of all orthogonal components led to a specific band at the expected molecular weight. The control reaction without addition of the modified synthetase resulted in no visible band. The success of the microscopic analysis highly correlates to the quality of the in-gel-fluorescence. High background fluorescence during ingel-analysis often results in unspecific staining of the microsomes. The microscopic analysis clearly shows a difference in the fluorescence intensity of the labeled Adora2a and the unspecific staining of the microsomes (right panel).

1. After the reaction is completed collect $2 \times 3 \mu$ of the translation mixture. Centrifuge the remaining mix at $16,000 \times g$ for $15 \mathrm{~min}$ and $4{ }^{\circ} \mathrm{C}$ and collect $2 \times 3 \mu \mathrm{l}$ of the supernatant. Resuspend the microsomal fraction in an equal volume of PBS in comparison to the volume of the translation mixture. Collect $2 \times 3 \mu$ l of the microsomal fraction.

2. Mix each aliquot with $3 \mathrm{ml} \mathrm{TCA}$ and incubate in a water bath at $80{ }^{\circ} \mathrm{C}$ for $15 \mathrm{~min}$. Store the aliquots for $30 \mathrm{~min}$ on ice or overnight at $4{ }^{\circ} \mathrm{C}$. 
3.4.2 In-Gel-

Fluorescence

and Autoradiography

3.4.3 Confocal Laser

Scanning Microscopy
3. The mixture is applied to a vacuum filtration system to separate non-incorporated ${ }^{14} \mathrm{C}$-leucine from the radioactively labeled protein. Filters with the collected protein are washed twice with TCA and twice with acetone. Dry the filters under the hood.

4. The filters are transferred into the scintillation vials and overlaid with $3 \mathrm{ml}$ scintillation cocktail. After an incubation time of $1 \mathrm{~h}$ with gentle shaking, scintillation vessels are counted in scintillation counter.

1. For preparation of SDS-PAGE samples take a $5 \mu$ l aliquot (Subheading 3.3.1, steps 1-3) or $10 \mu \mathrm{l}$ site-specifically labeled aliquot (Subheading 3.3.3, steps 1-5) of each prepared sample. Add $45 \mu \mathrm{l}$ water and $150 \mu \mathrm{l}$ cold acetone to the 5 or $10 \mu \mathrm{l}$ aliquots and incubate for $15 \mathrm{~min}$ on ice. Keep the fluorescently labeled samples in dark during the whole procedure. Centrifuge the samples at $16,000 \times g$ for $10 \mathrm{~min}$ at $4{ }^{\circ} \mathrm{C}$ and discard the supernatant.

2. Dry the pellets for $\mathrm{l} \mathrm{h}$ at $45^{\circ} \mathrm{C}$ in a thermo mixer with a shaking speed of $1000 \mathrm{rpm}$.

3. Resuspend the dried pellets in $20 \mu \mathrm{l}$ SDS-PAGE sample buffer and load the samples on a prepared $10 \%$ SDS-PAGE gel. Use a ladder with fluorescently labeled bands. Run the gel.

4. Transfer the gel to the fluorescence imaging system and detect the labeled protein bands. For Bodipy-TMR-lysine use a $532 \mathrm{~nm}$ laser and a $580 \mathrm{~nm}$ emission filter. Sulfo-Cy 5 can be detected with extinction at $633 \mathrm{~nm}$ and emission at $670 \mathrm{~nm}$.

5. Afterwards dry the gel for $60 \mathrm{~min}$ at $70{ }^{\circ} \mathrm{C}$ using a unigeldryer. The dried gels are exposed on a phosphorscreen for minimal 3 days and read out using a multi-mode imager.

1. For confocal laser scanning microscopy use $5 \mu \mathrm{l}$ of the fluorescently labeled protein in the microsomal fraction and dilute the sample in $20 \mu \mathrm{l}$ PBS. Add the mixture to a $\mu$-Ibidi-Slide.

2. Fix the slide. Use a plan-apochromat objective with a $60 \times$ or $100 \times$ magnification. Microsomal structures usually have a diameter of $1-10 \mu \mathrm{m}$.

3. Adjust the beam path to the coupled fluorescent dye. Standard dyes such as Cy 5 and FITC usually have a preset configuration. Cy5 is excited at $633 \mathrm{~nm}$ and the emission is detected with a long-pass filter above a wavelength of $670 \mathrm{~nm}$.

4. Adjust the microscope settings (laser intensity, gain master, focus, pinhole) according to the individual sample (see Note 17). 
1. Preparation of $\mathrm{CHO}$ lysate: The cultivation was carried out in a Biostat B-DCU II bioreactor (Sartorius Stedium Biotech $\mathrm{GmbH}$ ) at $37{ }^{\circ} \mathrm{C}$ with a chemical defined and serum-free media. Cells were harvested at a density of 3.5-5 $\times 10^{6}$ cells / $\mathrm{ml}$ by centrifugation at $200 \times g$ for $5 \mathrm{~min}$. The cell pellet was resuspended in $40 \mathrm{mM}$ HEPES-KOH, pH 7.5, $100 \mathrm{mM}$ $\mathrm{NaOAc}$ and $4 \mathrm{mM}$ DTT. The cell suspension was passed through a 20 -gauge needle to mechanically disrupt the cell membrane. Nuclei and cell debris were removed by a centrifugation step at $10,000 \times g$ for $10 \mathrm{~min}$. Raw lysate is applied to equilibrated Sephadex G-25 columns. Elution fractions with the highest measured RNA concentration were pooled and treated with micrococcal S7 nuclease to digest endogenous mRNA. The inactivation of the calcium-dependent nuclease was performed by adding $6.7 \mathrm{mM}$ EGTA to complex the calcium ions. The lysate was further supplemented with creatine kinase (f.c. $100 \mu \mathrm{g} / \mathrm{ml}$ ) to ensure the regeneration of ATP out of creatine phosphate. The prepared lysate was shock frozen in liquid nitrogen and stored at $-80{ }^{\circ} \mathrm{C}$.

2 . The cell-free reaction in a dialysis mode is performed in a two-chamber device. The reaction chamber $(1.1 \mathrm{ml}$, red lid) and the feeding chamber $(11 \mathrm{ml}$, colorless lid) are separated by a semipermeable membrane with a molecular weight cut-off of $10 \mathrm{kDa}$. Whereas inhibitory byproducts such as accumulating phosphates are removed, amino acids and energy components are delivered to the reaction chamber.

3. It is recommended to collect samples of the translation mix, supernatant, purification steps including flow through, washing fractions and elution fractions as well as buffer exchange procedure and concentration. The aliquots can be diluted in SDS-PAGE sample buffer and loaded to the SDS-PAGE in order to monitor the purity of the aminoacyl-tRNA-synthetase during the preparation.

4. Concentrate the synthetase to a concentration of $5 \mathrm{~g} / \mathrm{l}$ to ensure a minimal final concentration of $100 \mu \mathrm{M}$. If necessary repeat the concentration step.

5. The PCR product is purified with the QIAquick PCR Purification Kit and the concentration is determined by using a NanoDrop 2000c. For further analysis prepare a $1 \%(\mathrm{w} / \mathrm{v})$ agarose gel and load $1 \mu \mathrm{l}$ of the PCR product. The expected band size is 123 bps. 
6. The prepared RNA can be analyzed by gel-electrophoresis run in $1 \times$ TBE buffer (Subheading 2.2.1, item 11). Therefore, prepare a $2 \%(\mathrm{w} / \mathrm{v})$ agarose gel. Mix $2 \mu \mathrm{l}$ of the RNA with $6 \mu \mathrm{l}$ MOPS sample buffer (Subheading 2.2.2, item 6) and load the sample to the agarose gel. Use a RNA ladder. The expected band size is around 200 bps.

7. After centrifugation three phases are present: on top the aqueous phase with approximately $50 \%$ of the total volume, containing the RNA; a middle interphase that is nearly invisible and below the red phenol/chloroform phase. Try to isolate only the aqueous phase.

8. It is important that the components are dissolved completely to ensure the correct concentration. Vortex the components and store them in aliquots to avoid repeated thaw and freeze cycles.

9. The plasmid concentration can be varied and can be dependent on the chosen vector backbone. It is recommended to apply different plasmid concentrations in the range of $20-100 \mathrm{nM}$ to the cell-free protein synthesis reaction.

10. The fluorescent dye is susceptible to light. An illumination will decrease the fluorescence intensity of the dye. Use colored tubes or wrap the tube with aluminum foil. In addition, keep in mind that the precharged tRNACUA will address the amber stop codon whereas the precharged tRNAGAA will address statistically phenylalanine codons.

11. The optimal temperature for cell-free protein synthesis reaction in a $\mathrm{CHO}$ lysate is $30^{\circ} \mathrm{C}$. However, a temperature series is recommended to determine the optimal conditions for an individual protein in terms of folding and activity. The Adora2a-Nluc construct showed the highest Nluc activity at $27^{\circ} \mathrm{C}$.

12. It is recommended to analyze the incorporation efficiency of the non-canonical amino acid. With a low efficiency the subsequent labeling reaction will yield as well in a low amount of labeled protein. Therefore, two different methods can be utilized.

(a) Adding a reporter protein downstream of the amber stop codon. The reporter protein will only be translated if the amber stop codon is addressed by the tRNA and the non-canonical amino acid is transferred to the polypeptide chain. The intensity of the reporter protein signal is directly correlated to the amount of full-length protein and in conclusion to the incorporation efficiency. A comparison to a DNA construct without amber stop codon is possible. 
(b) Determine the amount of full-length protein with autoradiography. If the termination product has an adequate amount of incorporated ${ }^{14} \mathrm{C}$-leucine during the cell-free protein synthesis reaction and a detectable size, an additional band should be visible in the autoradiography. The ratio of full-length product and termination product can be calculated.

13. It is recommended to evaluate different agonist concentrations because at a defined concentration the binding sites of the cellfree synthesized Adora2a should be completely occupied resulting in a saturation effect in the BRET signal. The saturation effect supports the specific conformational rearrangement after ligand binding.

14. The non-canonical amino acid is solubilized in $0.5 \mathrm{M} \mathrm{NaOH}$. The alkaline $\mathrm{pH}$ of $\mathrm{NaOH}$ will shift the $\mathrm{pH}$ of the lysate that might result in an inactivation of enzymes involved in protein synthesis. Therefore, dilute the ncAA in translation mix, water and components that are not affected by an alkaline $\mathrm{pH}$.

15. Reactive groups of ncAA are often instable and susceptible to illumination. If the reactive group is inert a following coupling to a fluorescent dye is not possible. Therefore, keep the ncAA in the dark by using colored or wrapped tubes.

16. Copper has a toxic effect on proteins due to oxidative damage, but it is necessary as catalyst for the copper(I)-catalyzed alkyneazide cycloaddition (CuAAC). It is recommended to use different copper concentrations for the labeling reaction. For the Adora2a_amb construct we have seen a highest labeling efficiency with $200 \mu \mathrm{M}$ copper. The lowest copper concentration resulting in a detectable fluorescent band was $50 \mu \mathrm{M}$. Keep in mind that the concentration of THPTA has to be adjusted as well (threefold concentration of THPTA to $\mathrm{CuSO}_{4}$ ). In addition, it is recommended to adjust the incubation time of the labeling reaction. In general, $\mathrm{CuAAC}$ is a fast and efficient click reaction. A decrease in incubation time might enhance proteins activity.

17. The same microscopic settings that are chosen for the fluorescently labeled sample should be applied to the negative control to exclude an unspecific labeling of microsomal structures. Fluorescent dyes are usually highly hydrophobic and tend to stick unspecific to lipid membranes. It is recommended to evaluate the unspecific binding of different dyes to figure out the most suitable dye for certain applications. For our images a pinhole of 1 Airy unit $(118 \mu \mathrm{m})$, laser intensities of $22 \%$ (bright field) and $8 \%$ (fluorescence) resulted in the optimal recording of fluorescently labeled Adora2a. 
Acknowledgments

This work is supported by the European Regional Development Fund (EFRE), the German Ministry of Education and Research (BMBF, No. 031B0078A), and the German Research Foundation (DFG Priority Programme 1623).

\section{References}

1. Sarramegn V, Muller I, Milon A et al (2006) Recombinant $G$ protein-coupled receptors from expression to renaturation: a challenge towards structure. Cell Mol Life Sci 63 (10):1149-1164. https://doi.org/10.1007/ s00018-005-5557-6

2. Serebryany E, Zhu GA, Yan EC (2012) Artificial membrane-like environments for in vitro studies of purified G-protein coupled receptors. Biochim Biophys Acta 1818 (2):225-233. https://doi.org/10.1016/j. bbamem.2011.07.047

3. Andréll J, Tate CG (2012) Overexpression of membrane proteins in mammalian cells for structural studies. Mol Membr Biol 30 (1-2):52-63. https://doi.org/10.3109/ 09687688.2012 .703703

4. Jamshad M, Charlton J, Lin Y et al (2014) G-protein coupled receptor solubilization and purification for biophysical analysis and functional studies, in the total absence of detergent. Biosci Rep 35(2):e00188. https://doi.org/10. 1042/BSR20140171

5. Brödel AK, Sonnabend A, Roberts LO et al (2013) IRES-mediated translation of membrane proteins and glycoproteins in eukaryotic cell-free systems. PLoS One 8(12):e82234. https://doi.org/10.1371/journal.pone. 0082234

6. Zemella A, Thoring L, Hoffmeister C et al (2015) Cell-free protein synthesis: pros and cons of prokaryotic and eukaryotic systems. Chembiochem 16(17):2420-2431. https:// doi.org/10.1002/cbic.201500340

7. Thoring L, Dondapati SK, Stech $M$ et al (2017) High-yield production of "difficult-toexpress" proteins in a continuous exchange cell-free system based on $\mathrm{CHO}$ cell lysates. Sci Rep 7:11710. https://doi.org/10.1038/ s41598-017-12188-8

8. Daggett KA, Sakmar TP (2011) Site-specific in vitro and in vivo incorporation of molecular probes to study G-protein-coupled receptors. Mol Divers 15(3):392-398. https://doi.org/ $10.1016 /$ j.cbpa.2011.03.010
9. Quast RB, Mrusek D, Hoffmeister C et al (2015) Cotranslational incorporation of non-standard amino acids using cell-free protein synthesis. FEBS Lett 589(15):1703-1712. https://doi.org/10.1016/j.febslet.2015.04. 041

10. Quast RB, Ballion B, Stech M et al (2016) Cellfree synthesis of functional human epidermal growth factor receptor: investigation of ligandindependent dimerization in Sf21 microsomal membranes using non-canonical amino acids. Sci Rep 6:34048

11. Chin JW, Cropp TA, Anderson JC et al (2003) An expanded eukaryotic genetic code. Science 301(5635):964. https://doi.org/10.1126/sci ence. 1084772

12. Takimoto JK, Adams KL, Xiang Z et al (2009) Improving orthogonal tRNA-synthetase recognition for efficient unnatural amino acid incorporation and application in mammalian cells. Mol BioSyst 5(9):931-934. https://doi. org $/ 10.1039 / \mathrm{B} 904228 \mathrm{H}$

13. Edwards H, Schimmel P (1990) A bacterial amber suppressor in Saccharomyces cerevisiae is selectively recognized by a bacterial aminoacyl-tRNA synthetase. Mol Cell Biol 10 (4):1633-1641

14. Aren W, Dierckx Rudi AJO, Xiaoyun Z et al (2017) Potential therapeutic applications of adenosine A2A receptor ligands and opportunities for A2A receptor imaging. Med Res Rev 38(1):5-56. https://doi.org/10.1002/med. 21432

15. Chen J, Eltzschig HK, Fredholm BB (2013) Adenosine receptors as drug targets-what are the challenges? Nat Rev Drug Discov 12:265

16. Hoffmann C, Gaietta G, Bünemann $M$ et al (2005) A FlAsH-based FRET approach to determine $\mathrm{G}$ protein-coupled receptor activation in living cells. Nat Methods 2:171

17. Meritxell C, Javier B, Daniel M et al (2003) Homodimerization of adenosine A2A receptors: qualitative and quantitative assessment by fluorescence and bioluminescence energy transfer. J Neurochem 88(3):726-734. 
https://doi.org/10.1046/j.1471-4159.2003. 02200.x

18. Bissantz C (2003) Conformational changes of $G$ protein-coupled receptors during their activation by agonist binding. J Recept Signal Transduct Res 23(2-3):123-153. https://doi. org/10.1081/RRS-120025192

19. Brödel AK, Wüstenhagen DA, Kubick S (2015) Cell-free protein synthesis systems derived from cultured mammalian cells. In: Owens RJ (ed) Structural proteomics: high-throughput methods. Springer New York, New York, NY, pp 129-140

20. Thoring L, Wüstenhagen DA, Borowiak M et al (2016) Cell-free systems based on cho cell lysates: optimization strategies, synthesis of "difficult-to-express" proteins and future perspectives. PLoS One 11(9):e0163670. https://doi.org/10.1371/journal.pone.

0163670

Open Access This chapter is licensed under the terms of the Creative Commons Attribution 4.0 International License (http://creativecommons.org/licenses/by/4.0/), which permits use, sharing, adaptation, distribution and reproduction in any medium or format, as long as you give appropriate credit to the original author(s) and the source, provide a link to the Creative Commons license and indicate if changes were made.

The images or other third party material in this chapter are included in the chapter's Creative Commons license, unless indicated otherwise in a credit line to the material. If material is not included in the chapter's Creative Commons license and your intended use is not permitted by statutory regulation or exceeds the permitted use, you will need to obtain permission directly from the copyright holder. 